\section{Release Date} Thursday PM

Jniform Crime Reports

\title{
1981
}

1981

1981

1981

1981

1981

1981

1981

1981

1981

1981

- 1981

1981

1981

1981

1981

1981

1981

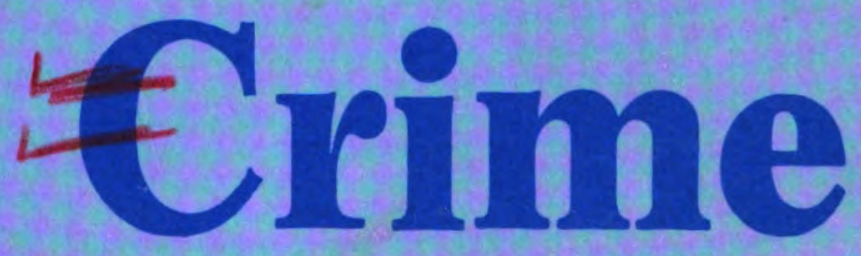

1981

1981

1981

1981

1981
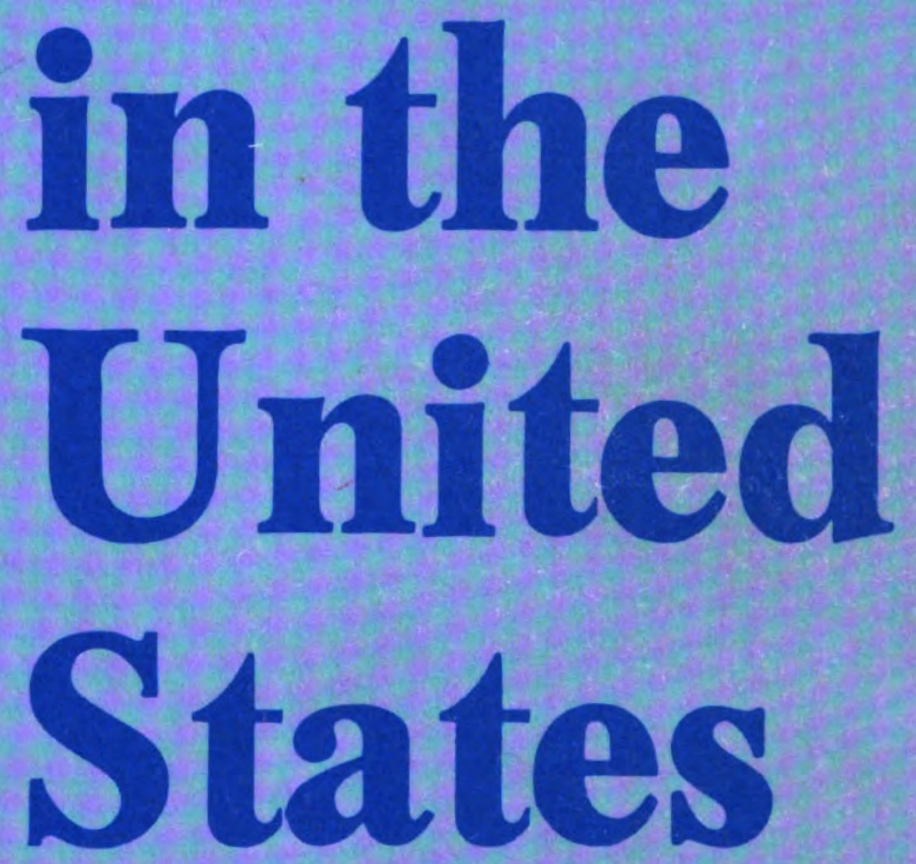

1981

$198^{1}$

o" 0 